\title{
The Abundance of Arbuscular Mycorrhiza Infective Propagules Under Galam Stand at Shallow Peat of South Kalimantan
}

\author{
Tri Wira Yuwati ${ }^{1}$, Annisa Noveani Rusalinda Rahmi ${ }^{2}$, Safinah Surya Hakim ${ }^{1}$ and Badruzsaufari ${ }^{2}$ \\ ${ }^{1}$ Banjarbaru Environment and Forestry Research and Development Institute, Banjarbaru, South Kalimatan \\ ${ }^{2}$ Faculty of Mathematics and Natural Science, Lambung Mangkurat University, Banjarbaru, South Kalimantan
}

\begin{abstract}
Colonization of arbuscular my corrhiza on plants has been reported to give benefit to plants, especially at extreme sites such as degraded peatland. Galam (Melaleuca cajuputi) is an indigenous peatland species which grows on acidic condition. The number of arbuscular mycorrhiza infective propagules is important to be determined concerning the galam regeneration due to its offered benefits that support colonization. This research aims to determine the abundance of arbuscular mycorrhiza infective propagules under galam stand and to describe symbiotic forms of AMF colonization on the roots of galam. The Most Probable Number (MPN) method, wet sieving, and root staining from the modification of Vierherlig et al., 1996, and the calculation of root's mycorrhizal colonization by grid line technique were the methods that were used in this research. The research used Complete Randomized Design (CRD) with a 5-fold factorial pattern. The results of this study indicated a significant difference between the abundance of AMF under galam stands at the depth of $0-15 \mathrm{~cm}$ and 15-30 cm respectively. The results of spores identification showed 4 genera of spores, namely: Glomus, Gigaspora, Scutellospora, and Acaulospora. The structure of root colonizations were hyphae, spores, vesicles, and arbuscular.
\end{abstract}

\section{Introduction}

Galam (Melaleuca cajuputi) is a woody plant species grows on shallow to moderately deep peat $(1-2 \mathrm{~m})$, which can adapt to acidic conditions with the $\mathrm{pH}$ range from 3-7. This plant has been recorded on shallow to moderately deep peat (1-2 m) in South Kalimantan [1] Moreover, Galam can grow under flooded conditions due to the adaptation of its metabolis ms [2]. It is called paperbark in English due to its thin and papery white bark [3]. Galam poles are used for construction purposes, sawn timber, high-quality fuelwood, and charcoal. Due to the high demand for timber, the availability of Galam has been decreasing due to overexploitation. Galam is not cultivated. It has relied on natural regeneration and no y ield management in the field. Thus, the sustainability of Galam trees is threatened.

Most plants, including Galam, associates with arbuscular mycorrhiza fungi (AMF). AMF has the main three functions including increasing plant growth, enhancing the absorption of soil nutrients, and protecting plants from the pest and disease attack and critical site condition [4]. To conserve Galam, we need to know the benefit of AMF colonization on Galam. One of the ways to determine the benefit of AMF colonization is by providing the number of infective propagules under the Galam trees. Infective propagules including spores and sporocarps, extraradical mycelium, and colonized roots; establish associations when they contact potential host-roots [5]. The objective of this research is to determine the abundance of arbuscular mycorrhiza infective propagules under Galam stand and to describe symbiotic forms of AMF colonization on the roots of Galam.

\section{Methods}

\subsection{Soil and root sample collection}

Soil samples and root samples were collected under the galam trees of Liang Anggang shallow peat at South Kalimantan. Root sample collection was carried out unproportionally from five galam trees; put in the envelopes and labeled. Soil samples were collected from 5 galam trees and within each tree, samples were replicated from 3 points. The number of soil samples was approximately $1 \mathrm{~kg}$ for each point at two different depth: $0-15 \mathrm{~cm}$ and $15-30 \mathrm{~cm}$. The soil samples were put in plastic bags and labeled.

\subsection{The Most Probable Number (MPN) method}

To obtain the number of infective propagules, a series of 4-fold dilutions were prepared. The soil samples of 1 $\mathrm{kg}$ were air-dried and sieved at $0.5 \mathrm{~cm} \times 0.5 \mathrm{~cm}$ sieve. This sample was used as a base for the next dilution and labeled substrate A. Then, $4 \mathrm{~kg}$ of soil sample was autoclave-sterilized, sieved, and dried. This sample is labeled as substrate B. Furthermore, $11 \mathrm{~kg}$ of soil was autoclave-sterilized, un-sieved. This sample then labeled as substrate $\mathrm{C}$. The MPN method was then started with putting $100 \mathrm{~g}$ of substrate $\mathrm{C}$ in each pot. Then, the dilution of substrate A and B was applied 50 $\mathrm{g}$ in each pot. The top layer of the pots was put $50 \mathrm{~g}$ of substrate C. Three maize seeds were then sown in each pot, watered daily, and grown for 4 weeks. After 4 weeks, the plant's roots were then harvested, cleaned, and stained with the modification of the Vierheilig method [6]. In this method, the root samples were 
washed with tap water, soaked them in $\mathrm{KOH} 10 \%$ for 24 hours, soaked in $\mathrm{HCl} 0.1 \mathrm{~N}$ for 24 hours, and ink + vinegar 5\% solution for 24 hours. The stained root samples were then checked for mycorrhizal colonization, counted, and reported as infected $(+)$ or not infected (-).

\subsection{The wet sieving method for isolating the AMF spores}

One hundred grams of soil sample was mixed with $1000 \mathrm{ml}$ of tap water and mixed well. Then, it was poured onto a series of sieve $250,125,75$, and $63 \mu \mathrm{m}$. The particle that was trapped in the sieve was then moved onto a Petri dish, checked, and counted under a stereomicroscope. The spores were then distinguished based on color and size.

\subsection{Morphological identification of arbuscular mycorrhiza spores}

There were six genera of arbuscular mycorrhiza spores which form a symbiosis with plants namely Glomus, Gigaspora, Scutellospora, Acaulospora, Enthrophospora, and Sclerocystis. The spores were identified based on color, wall layer, Melzer's reaction, bulbous suspensor, and sustending hyphae [7].

\subsection{Data analysis}

The infective propagules were counted using a formula

$$
\log \Omega=\mathbf{x} \cdot \log \mathbf{a}-\mathrm{K}
$$

$\mathbf{\Omega}$ : the number of infective propagules

$\mathbf{X}$ : average number of infected pots

a: dilution factors

K: taken from Sieverding [8].

The number of spores and the arbuscular mycorrhiza colonization in plant's roots was presented des criptively.

\section{Results}

\subsection{Number of infectives propagules}

The number of infective propagules under the Galam stand is presented in Table 1.

Table 1. The number of infective propagules under the Galam stand.

\begin{tabular}{cc}
\hline Sample number & $\begin{array}{c}\text { Number of infective propagules (per } \\
50 \text { gram soil) }\end{array}$ \\
\hline 1 & \pm 85113.80 \\
2 & \pm 55667.28 \\
3 & \pm 85113.80 \\
\hline
\end{tabular}

The number of infective propagules under the Galam stand varied with the lowest of $\pm 55667,28$ and the highest of $\pm 85113,8$. The average number of arbuscular mycorrhiza infective propagules under the Galam stand was $\pm 75298,29$.

\subsection{The arbuscular mycorrhiza spores}

The arbuscular mycorrhiza spores that were isolated under the Galam trees were varied. There were six species namely Glomus sp. 1, Glomus sp. 2, Glomus sp.3, Gigaspora sp., Acaulospora sp., and Scutellospora sp. The spores were presented in Figure 1.

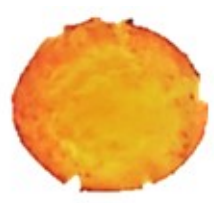

Glomus sp.1

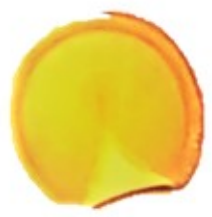

Gigasporasp

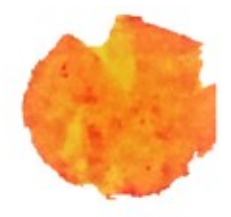

Glomus sp.2

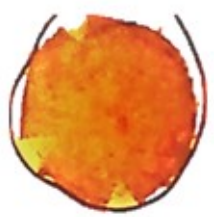

Acaulosporasp.

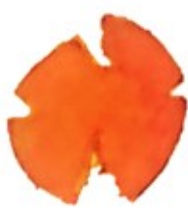

Glomus sp.3

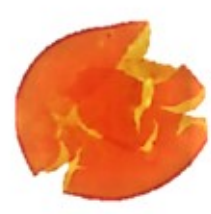

Scutellosporasp.
Figure 1. Arbuscular mycorrhiza spores under Galam stand at shallow peat of South Kalimantan

The average number of spores per 100-gram soil is presented in Table 2.

Table 2. The average number of spores per 100-gram soil under galam trees.

\begin{tabular}{cc}
\hline Soil Depth & $\begin{array}{c}\text { Mean number of spores per } \\
\text { 100-gram soil }\end{array}$ \\
\hline $0-15 \mathrm{~cm}$ & 508.4 \\
$15-30 \mathrm{~cm}$ & 337.2 \\
\hline
\end{tabular}

The average number of spores under galam trees at the soil depth of $0-15 \mathrm{~cm}$ and $15-30 \mathrm{~cm}$ were 508.4 and 337.2 , respectively.

\subsection{Colonization of arbuscular mycorrhiza on roots}

The percentage of roots colonization is presented in Table 3.

Table 3. Arbuscular mycorrhiza colonization on galam roots at shallow peat of South Kalimantan.

\begin{tabular}{ccc}
\hline $\begin{array}{c}\text { Soil depth } \\
(\mathrm{cm})\end{array}$ & $\begin{array}{c}\text { Colonization } \\
\text { percentage }(\%)\end{array}$ & $\begin{array}{c}\text { O'Connor } \\
(2001)\end{array}$ \\
\hline $0-15$ & 70 & High \\
$15-30$ & 57.42 & High \\
\hline
\end{tabular}

The arbuscular mycorrhiza colonization on the roots of galam at shallow peat of Ka limantan at 0-15 cm and $15-30 \mathrm{~cm}$ depth were $70 \%$ and $57.42 \%$, 
respectively. Both were categorized as high according to O'Connor [10].

The symbiotic forms of AMF colonization on the Galam roots were found namely arbuscular and vesicular (Figure 2).
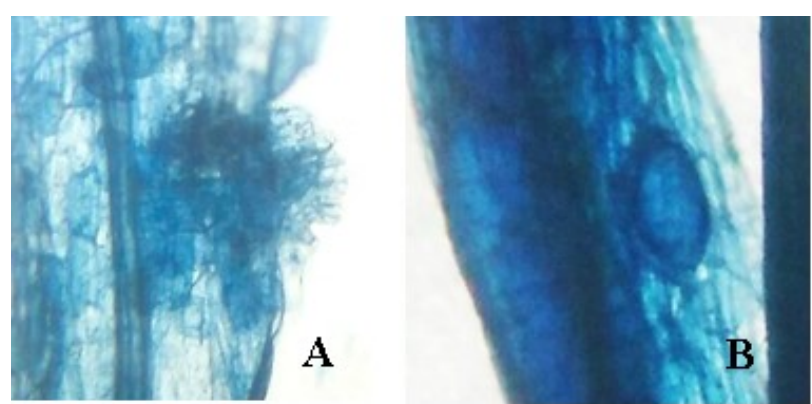

Figure 2. The symbiotic forms of AMF colonization on Galam roots showing arbuscular (left) and vesicular (right)

The AMF arbuscular structures look like a tree; consists of intraradical hyphae. Arbuscules functions as a place for the exchange of nutrients and carbon between AMF and host plant. The molecular and structural organizations of arbuscular facilitate and regulate the processes of nutrient exchange [9]. The vesicles are terminal swellings of hyphae formed inter and intracellularly having a storage function [7].

\section{Discussion}

The average number of infective propagules under the galam tree at shallow peat of South Kalimantan was \pm 75298,29 per 50-gram soil; or 1505 per gram soil. According to The Indonesian Ministry of Agriculture Decree No. 70/ 2011 on Biofertilizer Standard, the number of arbuscular mycorrhiza propagules shall higher than 50 per gram soil. Moreover, if we are looking at the root colonization at $0-15 \mathrm{~cm}$ and 15-30 $\mathrm{cm}$, both exceeded more than 50\%. According to O'Connor [10], it was categorized as high colonization. Thus, according to The Indonesian Ministry of Agriculture Decree No. 70/ 2011 on Biofertilizer Standard, the minimum percentage of colonization for the biofertilizer is more than $50 \%$. It means, from the number of infective propagules and arbuscular mycorrhiza colonization, we can determine that Galam can get the benefit from arbuscular mycorrhiza.

Glomus was the species that most found under the Galam trees at shallow peat of South Kalimantan, Glomus is known to be adaptable in various soil and has the widest habitat [11]. Glomus has a high tolerance to extreme conditions and can form symbiosis [12]. Ramadhani [13] added that Gigaspora is also able to survive in the extreme condition such as acidic or drought. Yuwati et al [14] also found that Glomus sp was dominantly found at deep after burnt peatland at Central Kalimantan. The number of spores was higher at $0-15 \mathrm{~cm}$ than $15-30 \mathrm{~cm}$. The deeper the peat soil, the mo isture is higher. Mo is ture could accelerate the spores to germinate [15]. It means, the deeper the soil, the arbuscular mycorrhiza could be in the form of hyphae than spore. Moreover, Delvian [15] stated that high soil moisture content could accelerate the spore to germinate and form colonization on the host plant's roots. On the contrary, the formulation of new spores will increase the dry condition and roots colonization will be lower. It is a natural response of arbuscular mycorrhiza to keep its existence in nature.

One of the ways to enhance land productivity is by silvicultural techniques; one of them is the utilization of biofertilizer. Considering the number of infective propagules, some spores, and colonization rates, the arbuscular mycorrhiza spores under the galam trees at shallow peat of South Kalimantan is promising to be utilized as biofertilizer.

\section{Conclusion}

The average number of arbuscular mycorrh iza infective propagules under the Galam stand of shallow peat South Kalimantan were 55667-85113 propagules per 50 -gram soil. The number of spores at $0-15 \mathrm{~cm}$ and $15-30 \mathrm{~cm}$ soil depth were 508 and 337 , respectively. There were four genera of arbuscular mycorrh iza spores found namely Glomus, Gigaspora, Acaulospora, and Scutellospora. Among the four genera, Glomus was dominantly found. The colonization of arbuscular mycorrhiza on the roots was ranging from $57-70 \%$; categorized as high. These findings showed that Galam was able to get the benefit of AMF colonization and the soil under galam trees was the potential to be developed as biofertilizer.

\section{References}

1. W. Giesen. Vegetation of the Negara River Basin. In Zieren, M., Permana, T and Giesen, W (eds.). Proceeding of Workshop on Conservation of Sungai Negara Wetlands Barito Basin, Banjarbaru (6-8 March 1989), (1990)

2. S. Kogawara, T. Yamanoshita, M. Norisada, M. Masumori, and K. Kojima. Photosynthesis and photoassimilate transport during root hypoxia in Melaleuca cajuputi, a flood-tolerant species, and in Eucalyptus camaldulensis, a moderately flood-tolerant species. Tree Physiology 26, 14131423, (2006)

3. W. Giesen. Case Study: Melaleuca cajuputi (gelam) - a useful species and an option for paludiculture in degraded peatlands. Sustainable Peatlands for People \& Climate (SPPC) Project. Wetlands International. p 16, (2015)

4. S.E. Smith, D.J. Read. Mycorrhizal Symbiosis. $3^{\text {rd }}$ eds. Elsevier. Amsterdam, (2008) 
5. P. Guadarrama, S.C. Arguero, J.A.R. Zapata, S.L.C. Ricalde, and J.A. Sanchez. Propagules of arbuscular mycorrhizal fungi in a secondary dry forest of Oaxaca Mexico. International Journal of Tropical Biology.56(1); 269-277, (2008)

6. H. Vierheilig, A.P. Coughlan, U.R.S. Wyss, and Y. Piche. Ink and Vinegar: A simple staining technique for Arbuscular Mycorrhizal Fungi. Applied and Environmental Microbiology. 64: 5004-5007, (1996)

7. Brundrett, M. N. Bougherr, B. Dells, T. Grove, N. Malajczuk. Working with mycorrhizas in forestry and agriculture. Bernie De1l, Murdoch University. Murdoch, WA. 374 p. (1996)

8. E. Sieverding $\backslash$. Vesicular-arbuscular mycorrhizal management in tropical agrosystems. Deuttsche Gesellschat Technische Zusammenarbeit (GTZ), Eschborn, Germany, (1991)

9. Z.M. Solaiman, B. Mickan. Use of Mycorrhiza in Sustainable Agriculture and Land Restoration In Solaiman, Z,M., Abbott, L.K.,and Varma, A. (eds) 2014. Mycorrhizal Fungi: Use in Sustainable Agriculture and Land Restoration. Springer, Heidelberg, (2014)

10. P.J.O. O'Connor, S.E. Smith, and F.A. Smith. Arbuscular Mycorrhizal Associations in The Southern Simpson Desert. Australian Journal of Botany. 49: 493 - 499, (2001)
11. Hermawan, H.A. Muin, \& R.S. Wulandari. Kelimpahan Fungi Mikoriza Arbuskula (FMA) pada tegakang ekaliptus (Eucalyptus pellita) berdasarkan tingkat kedalaman di lahan gambut. Jurnal Hutan Lestari. 3(1): 124-132, (2015)

12. F. Sianturi, R. Linda, \& S. Khotimah. 2005. Kepadatan spora fungi Mikoriza Vesikular Arbuskular pada tiga tingkat kematangan gambut di Kawasan Hutan Lindung Gunung Ambawang Kabupaten Kubu Raya. Jurnal Protobiont. 4 (2): 96-102, (2005)

13. F. Ramadhani. Pengaruh Pemberian Pupuk Rock Fosfat dan Berbagai Jenis Mikoriza Vesicular Arbuskular terhadap Produksi Tanaman Kedelai (Glycine max. L. Merril) pada Tanah Gambut Ajamu Labuhan Batu. Skripsi Fakultas Kehutanan USU Medan, (2007)

14. T.W. Yuwati, S.S. Hakim, D. Alimah, B. Hermawan, \& A.A.Musthofa. Keanekaragaman Spora Mikoriza Arbuskula di Hutan Rawa Gambut Kalimantan Tengah. In: Diana, Sulistioadi, Y.B., Karyati, Sarminah, S., Widiati, K.Y., Kuspradini, H., Sari, D.R. dan Mulyadi,R. (eds) Prosiding Seminar Nasional Silvikultur ke-IV, Balikpapan, (2017)

15. Delvian. Peranan Ekologi dan Agronomi Cendawan Mikoriza Arbuskula. Sumatera Utara (ID): USU Press, (2006) 